\title{
TRYPANOSOMIASIS IN MICE OF THE CHERNOBYL ZONE OF RADIOACTIVE CONTAMINATION
}

O. V. SEMENKO, Candidate of Veterinary Sciences, Associate Professor Department of Pharmacology, Parasitology and Tropical Veterinary Medicine https://orcid.org/0000-0002-6453-6192

National University of Life and Environmental Sciences of Ukraine, Kyiv, Ukraine

A. I. LYPSKA, Doctor of Biological Sciences, Senior Research Fellow

Head of the Department of Radiobiology and Radioecology

https://orcid.org/0000-0001-6858-2201

Institute for Nuclear Research of National Academy of Sciences of Ukraine, Kyiv, Ukraine

D. O. VISHNEVSKY, Head of the Department of Ecology of Flora and Fauna https://orcid.org/0000-0002-7824-5812

Chornobyl radiation and ecological biosphere reserve, Kyiv, Ukraine

O. O. BURDO, Junior Research Fellow

Department of Radiobiology and Radioecology

https://orcid.org/0000-0003-3892-0198

Institute for Nuclear Research of the National Academy of Sciences of Ukraine, Kyiv, Ukraine

O. B. BOIKO, Graduate Student

Department of Pharmacology, Parasitology and Tropical Veterinary Medicine https://orcid.org/0000-0002-1074-3209

National University of Life and Environmental Sciences of Ukraine, Kyiv, Ukraine

V. F. GALAT, Doctor of Veterinary Sciences, Professor

Department of Pharmacology, Parasitology and Tropical Veterinary Medicine https://orcid.org/0000-0002-3844-2475

National University of Life and Environmental Sciences of Ukraine, Kyiv, Ukraine

M. V. GALAT, Candidate of Veterinary Sciences, Associate Professor

Department of Pharmacology, Parasitology and Tropical Veterinary Medicine https://orcid.org/0000-0001-8881-0865

National University of Life and Environmental Sciences of Ukraine, Kyiv, Ukraine E-mail:galat_mv@nubip.edu.ua

Abstract. One of the most obvious and long-lasting consequences of the Chornobyl nuclear power plant accident is the creation of an exclusion zone and a zone of unconditional (compulsory) alienation. The effect of succession is manifested in the fact that a significant part of aquatic and terrestrial ecosystems as of 1986 was artificial or semi-artificial systems that were under regulatory control by humans. Parasitic systems are one of the informative indicators of processes occurring in ecosystems. Any changes in the host population lead to changes in the parasite population. The degree of imbalance of the "parasite-host" system 
depends on the nature and strength of the influence of external factors. In order to study the parasitic systems of the exclusion zone as informative indicators, rodents were selected. Among the rodents studied for the presence of causative agents of parasitic diseases were field (Apodemus agrarius) and yellow-necked (Apodemus flavicollis) mice. A study of them was conducted for the presence of causative agents of blood-borne parasitic diseases.

Examination of mice blood smears revealed the presence of causative agents of blood parasitic and infectious diseases in all of the investigated animals. Among the causative agents of these diseases, Trypanosoma spp., Babesia spp., Rickettsia spp. and others were identified. Trypanosoma spp. was identified for the first time on the territory of Ukraine in blood smears of 3 mice among investigated, which were $25 \%$ (95\% confidence intervals 6.8-54.1). The number of parasites in 200 fields of view of the microscope from the studied mice varied from 2 to 25.

Keywords: hemoparasitic diseases, mice, Apodemus flavicollis, Apodemus agrarius, Trypanosoma spp.

\section{Introduction}

One of the most obvious and long-lasting consequences of the Chornobyl nuclear power plant accident is the creation of an exclusion zone and a zone of unconditional (compulsory) alienation. Here, the negative impact of radioactive contamination on humans and the environment has manifested itself to the maximum. This led to the evacuation of the population and the curtailment of economic activity in an area of $2.600 \mathrm{~km}^{2} .90-95 \%$ of this area has no systematic human activity and the regime is equal to the reserve (Balashov et al., 1992). Ecosystems formed in the exclusion zone are influenced by several key factors. Among them - radioactive contamination, succession, and climate change.

A characteristic feature of radioactive contamination of Chornobyl origin is the spatial heterogeneity of density, radionuclide composition, and physicochemical forms of precipitation. Most of the radionuclides were part of the "hot particles". The largest "hot particles" fell in the near zone. Contamination of most of the zone territory was formed by the finely dispersed fraction of "hot particles". In the form of radioactive contamination outside the ex- clusion zone, the condensation component is dominated. Today, the radiation situation is formed by the following elements: ${ }^{137} \mathrm{Cs}$, ${ }^{90} \mathrm{Sr}, \mathrm{Pu}$ (isotopes 238, 239, 240), ${ }^{241} \mathrm{Am}$.

The effect of succession is manifested in the fact that a significant part of aquatic and terrestrial ecosystems as of 1986 was artificial or semi-artificial systems that were under regulatory control by humans. These are agro-landscapes, monocultural forests, irrigation and drainage systems, inhabited localities. The removal of regulatory control has led to the inclusion of natural mechanisms of dynamics, including catastrophic (fires, outbreaks, floods, etc.) (Vishnevskiy et al., 2004). That is, a significant part of ecosystems is in a state far from equilibrium, where the processes of succession are active.

The testamentary effect is the result of a radical reduction in economic activity and the creation of a strict protection regime. The increase in the number of background species and the appearance of rare species of animals and plants has been recorded for several years after the accident. We should also take into account the high landscape diversity and a large area of the exclusion zone.

Climatic factors are external to natural complexes and do not depend on 
them. In recent years, climate change has had a significant impact on the hydrological regime and vegetation.

Based on the above, we can say that the dynamics of ecosystems in the exclusion zone is unique. The need for its study is due to a number of reasons: management of water and forest resources, assessment of the significance of natural complexes, the study of parasitic systems and zoonoses, and so on.

Parasitic systems are one of the informative indicators of processes occurring in ecosystems. Any changes in the host population lead to changes in the parasite population. The degree of imbalance of the "parasite-host" system depends on the nature and strength of the influence of external factors (Semenko et al., 2017; Semenko et al., 2020).

In order to study the parasitic systems of the exclusion zone as informative indicators, rodents were selected. Among the rodents studied for the presence of causative agents of parasitic diseases were field (Apodemus agrarius) and yellow-necked (Apodemus flavicollis) mice.

\section{Analysis of recent research and publications}

Trypanosomoses are diseases, which are caused by parasites of the genus Trypanoso$m a$. They could be extracellular (Trypanosoma evansi) and intracellular (Trypanosoma cruzi) parasites (Riedel, 1975; McGhee et al., 1980; Nagle et al., 1980; Rodriguez-Morales et al., 2011; Norman et al., 2013; O'Connell et al., 2015). Species of this genus may differ in their transmission types (Sato et al., 2003; Rocha et al., 2004; Morio et al., 2008; Rotureau et al., 2013). Species, which are independent of tsetse flies belong to non tsetse transmitted animal trypanosomoses (NTTAT) (Schaub et al., 1994; Sharma et al., 2009). Investigation of these para- sites, their control measures are coordinated with OIE Non Tsetse Transmitted Animal Trypanosomoses Network according to support of a global strategy for the control of NTTAT. NTTAT are spread in Africa, Asia, Latin America, and Europe.

We haven 't found information about the spreading of these parasites on the territory of Ukraine. But on the territory of Russia, causative agents of breeding disease of one-hoofed animals (Trypanosoma equiperdum) and surra of horses and camels (T. evansi (Fig. 1)) have been registered (Georgiu, 2015). T. evansi may cause in experimentally infected mice splenomegaly and hepatomegaly (Ghaffar et al., 2016) and might be a reason for human disease (Joshi et al., 2005).

Trypanosome species that are transmitted without tsetse flies include T. evansi, $T$. equiperdum, and T. vivax. These species cause surra, dourine, and nagana in a wide range of domestic animals like cattle, buffalo, horse, camel, small ruminants, and others. All these diseases lead to economic losses in endemic areas (Hoare et al., 1972; Stevens et al., 1999; Powar et al., 2006; Otto et al., 2010; Schwan et al., 2016). And also, these species could parasitize in the body of rodents such as mice.

One of the species, which could parasitize in the body of rodents and is transmitted by fleas is Trypanosoma (Herpetosoma) lewisi. Animals are infected by the oral route, through contamination by flea feces or ingestion of fleas (Shaw et al., 1973; Guerrero et al., 1997; Desquesnes et al., 2002). Trypanosoma musculi is also transmitted between mice by ingestion of infected fleas. These trypanosomes are of similar morphology, making it difficult to distinguish them by microscopy. There are also few records of human infection cases caused by T. lewisi (Viens et al., 1972; Ponzi et al., 1984; Howie et al., 2006; Rayat et al., 2014; Hong et al., 2017). 

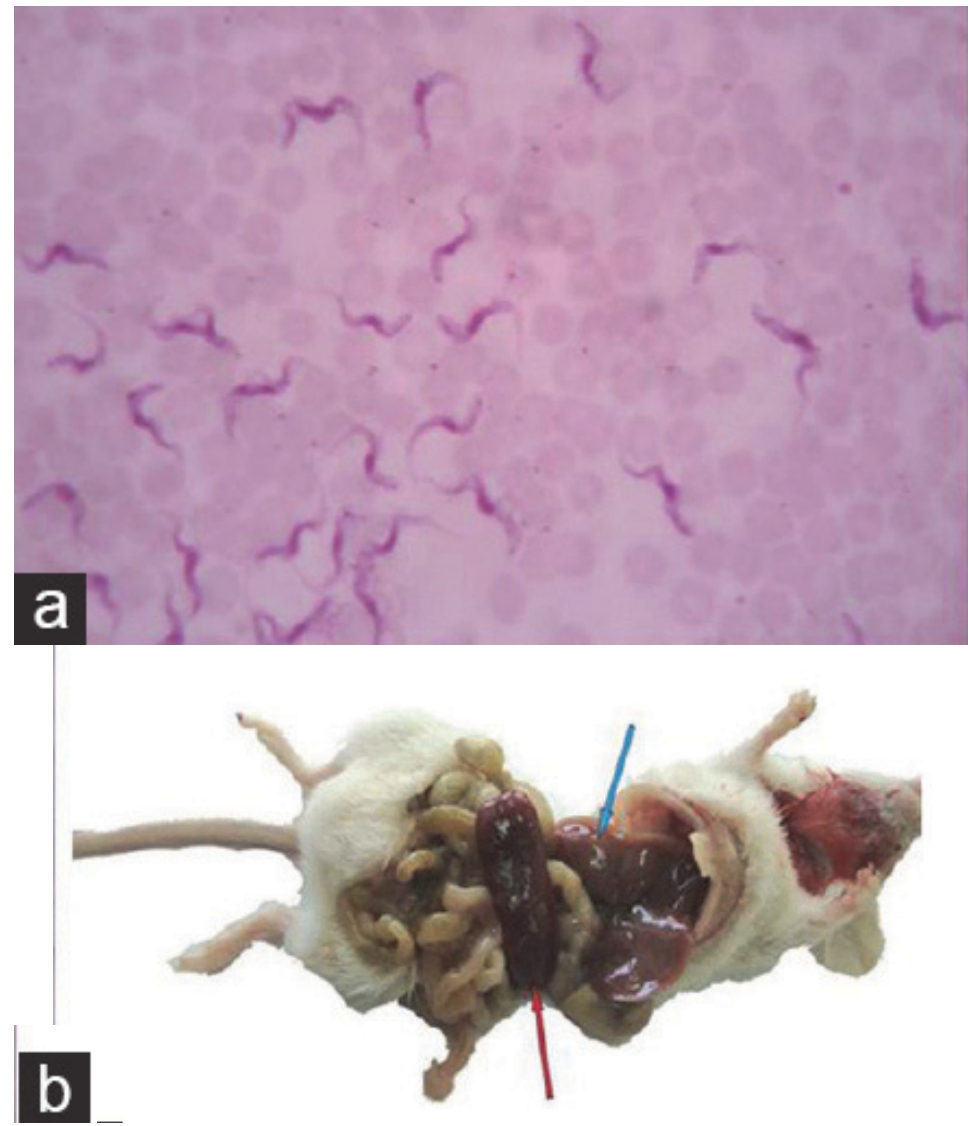

Fig. 1. (a) Giemsa stained blood smears from mice infected with T. evansi, $\times 1000$; (b) Splenomegaly (red arrow) and hepatomegaly (blue arrow) in experimentally infected mice with T. evansi (Ghaffar et al., 2016)

3 morphologically indistinguishable subspecies of Trypanosoma brucei are involved in a complex transmission cycle between humans, tsetse, and reservoir hosts. These subspecies cause Gambian and Rhodesian sleeping sickness or coexist with the other trypanosomes in reservoir hosts and vectors (Dumas et al., 1999). And according to the results of investigations, T. cruzi DNA has been identified in mummified human beings in South America dating back 4000 years, which means that human beings were exposed to African trypanosomes concomitantly with their evolution (Guhl et al., 2000; Barrett et al., 2003; Otero et al., 2012).
Methods for identification of trypanosomes include rodent subinoculation, cryopreservation, in vitro methods, isoenzyme electrophoresis, molecular characterization, population genetics methods, true phylogenetic methods, and others (Dumas et al., 1999).

Pentamidine, suramin, melarsoprol (latestage disease with central nervous system disorders), eflornithine are licensed for the treatment of trypanosomiases in humans. Nifurtimox, although only licensed for use against Chagas' disease. Diminazene (berenil), a veterinary medicament, has also been used occasionally without a license (Pepin 
et al., 1994; Barrett et al., 2003; Pereira et al., 2009; Shikanai-Yasuda et al., 2012). But such species as T. vivax, according to the research, is resistant to diminazene aceturate but sensitive to isometamidium chloride (Desquesnes et al., 1995).

To the principles of control of trypanosomiases belong treatment of infected individuals, active case finding with mobile teams, vector control, personal prophylaxis, and serological control of blood banks (Barrett et al., 2003).

\section{Materials and methods of research}

The research was carried out on the $2^{\text {nd }}$ landfill $\left(51^{\circ} 22^{\prime} 20.60\right.$ " $\mathrm{N} 30^{\circ}$ 8'26.94" E) located on the drained areas at the bottom of the cooling reservoir of the Chornobyl nuclear power plant. The strength of the exposure dose of $\gamma$-radiation and the flux density of $\beta$-particles above the soil surface in places of catching animals were determined by $\gamma$-, $\beta$-radiometer "Pripyat" RKS 20.3.

Catching murine rodents of various species, which are widely used in radiobiological studies as indicators, were carried out in the second half of September 2020 using traps of the Sherman system. The duration of catches at the landfill was 3 days with daily inspection of traps. After capture, the animals were taken to the laboratory of the Institute for Nuclear Research of the National Academy of Sciences of Ukraine (Kyiv, Ukraine), examined, registered with individual numbers and values of the date and place of capture, species name, gender, body weight. Species affiliation of individuals was determined by morphological characteristics. Age was determined by a set of features: weight, body length, development of reproductive organs, and thymus. Thin blood smears were prepared from a drop of blood obtained from the heart. Staining of smears and their further ex- amination was carried out on the basis of the Department of Pharmacology, Parasitology and Tropical Veterinary Medicine of the National University of Life and Environmental Sciences of Ukraine. A set of Leucodif 200 (LDF 200) kit in accordance with the manufacturer's instructions was used in order to stain the smears. Examination of stained blood smears was performed using a microscope with $\times 1000$ and $\times 1150$ magnification.

\section{Results of the research and their discussion}

12 mice were caught using traps of the Sherman system and then investigated. Among them, 6 mice were field (Apodemus agrarius) and 4 - yellow-necked (Apodemus flavicollis). For two mice, the species was not identified.

6 mice were females and 5 - males. For one mouse, age was not identified.

According to the blood smear examinations from mice of Chornobyl Radioecological Biosphere Reserve, Trypanosoma spp. agents were revealed for the first time in Ukraine (Fig. 2, 3). They were identified in blood smears from 3 mice, which accounted for $25 \%$ (95\% confidence intervals 6.8-54.1). 2 of 3 positive mice were males Apodemus agrarius and 1 was unidentified gender Apodemus flavicollis.

The number of parasites in 200 fields of view of the microscope from the studied mice varied from 2 to 25 .

Sizes of the Trypanosoma spp. in blood smears were 30-40 $\mu \mathrm{m}$ in length.

Also during blood smear microscopic examinations, Babesia spp. was identified in 8 mice $(66.7 \%$; $95 \%$ confidence intervals 37.7-88.4), Rickettsia spp. - in 9 mice (75\%; 95\% confidence intervals 45.9-93.2); anisocytosis, polychromasia, poikilocytosis, basophilic granularity, plasma cells, reactive lymphocytes, Jolly little bodies, and hypochromic erythrocytes were observed. 
О. В. Семенко, А. І. Липська, Д. О. Вишневський, О. О. Бурдо, О. Б. Бойко,

В. Ф. Галат, М. В. Галат

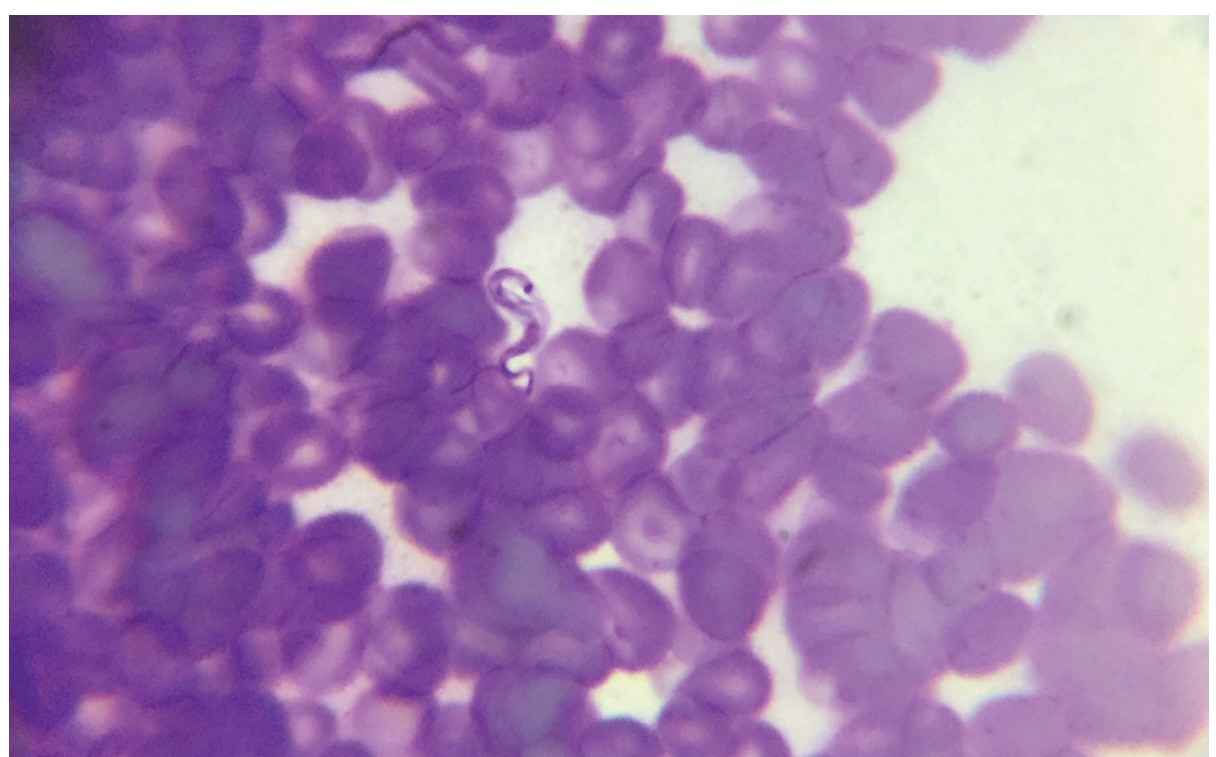

Fig. 2. Leucodif 200 (LDF 200) stained blood smears from mice infected with Trypanosoma spp., $\times 1000$

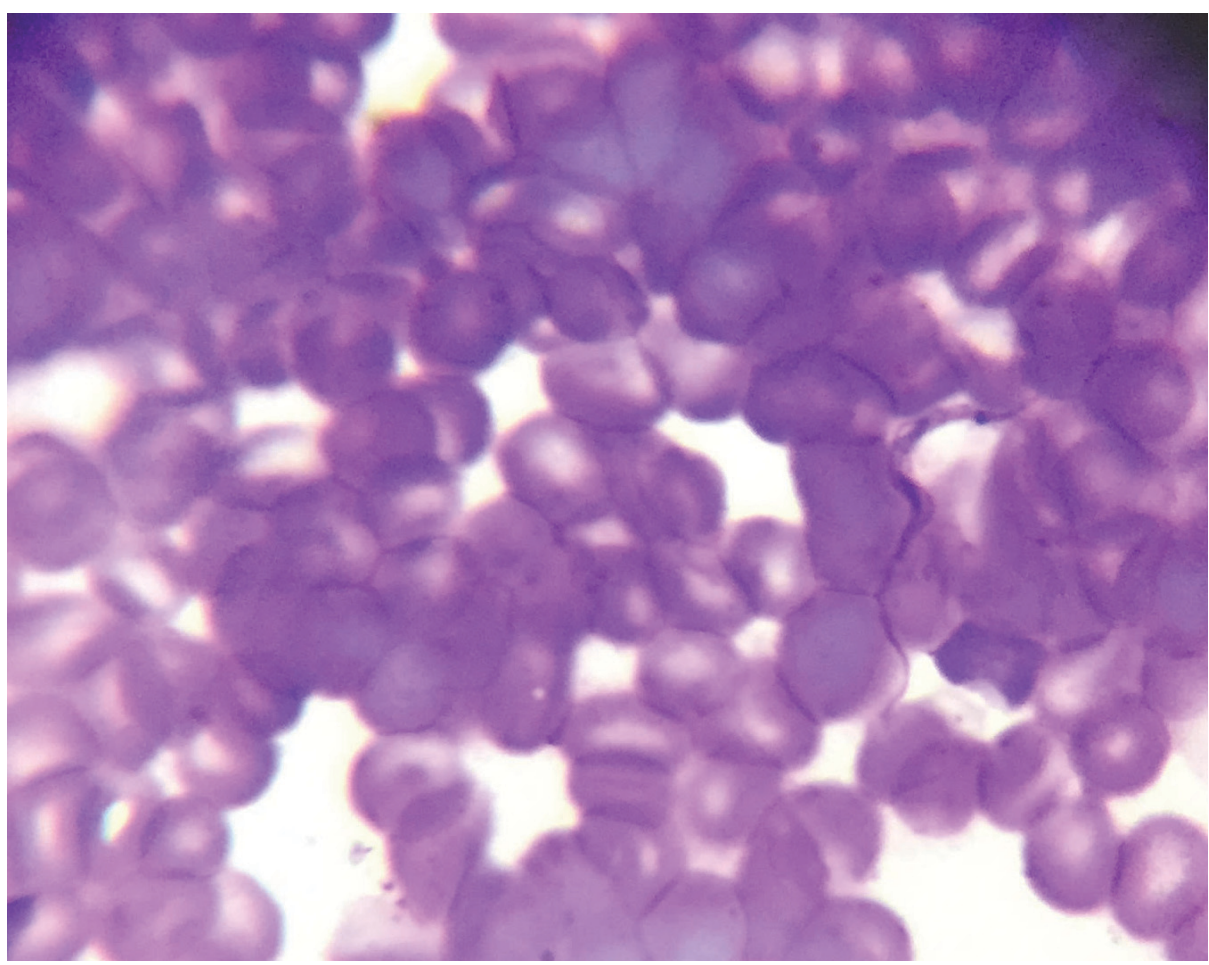

Fig. 3. Leucodif 200 (LDF 200) stained blood smears from mice infected with Trypanosoma spp., $\times 1000$ 


\section{Conclusions and future perspectives}

This is the first identification of the Trypanosoma spp. in Ukraine. Thus, murine rodents are hosts for a significant number of blood parasites, both infectious and parasitic. Some of them are also causative agents of zoonotic diseases. Further research, including PCR investigation, is essential to identify species of these agents, possible routes of transmission to murine rodents, and risks of transmission from animals to humans. In our future investigations we plan to conduct also genetic analysis to establish the registered species of Trypanosoma spp., Babesia spp., and Rickettsia spp. not only morphologically in blood smears.

\section{References}

Georgiu, H. (2015). Protytrypanosomnyi T. equiperdum antigen [Antitrypanosomal T. equiperdum antigen]. Rosiyskyi veterynaryi zhyrnal, 3, 22-23.

Balashov, L., Gaychenko, V., Krizhanivsky, V., \& Frantsevich, L. (1992). Vtorynni ecologichni sluzhby na evacuyovanyi terytoryi [Secondary ecologic services in the evacuated territory]. Oykumen, 2, 31-43.

Barrett, M. P., Burchmore, R. J., Stich, A., Lazzari, J. O., Frasch, A. C., Cazzulo, J. J., \& Krishna, S. (2003). The trypanosomiases. The Lancet, 362(9394), 1469-1480.Desquesnes, M., Ravel, S., \& Cuny, G. (2002). PCR identification of Trypanosoma lewisi, a common parasite of laboratory rats. Kinetoplastid Biology and Disease, 1(1), 2.

Desquesnes, M., de la Rocque, S., \& Peregrine, A. S. (1995). French Guyanan isolate of Trypanosoma vivax resistant to diminazene aceturate but sensitive to isometamidium chloride. Acta Tropica, 60, 133-136.

Dumas, M., Bouteille, B., \& Buguet, A. (2013). Progress in human African trypanosomiasis, sleeping sickness. Springer Science \& Business Media.
Hoare, C. A. (1972). The trypanosomes of mammals. A zoological monograph. Oxford, UK: Blackwell Scientific Publications.

Hong, X.-K., Zhang, X., Fusco O. A., Lan, Y.-G., Lun, Z.-R., \& Lai, D. (2017). PCR-based identification of Trypanosoma lewisi and Trypanosoma musculi using maxicircle kinetoplast DNA. Acta Tropica, 171, 207-212.

Howie, S., Guy, M., Fleming, L., Bailey, W., Noyes, H., Faye, J. A., ... \& Corrah, T. (2006). A Gambian infant with fever and an unexpected blood film. PLoS Medicine, 3(9), 355.

Ghaffar, M. A., El-Melegy, M., Afifi, A. F., Bahaa El Deen, W., El-Kady, N., \& Atia, A. F. (2016). The histopathological effects of Trypanosoma evansi on experimentally infected mice. Menoufia Medical Journal, 29(4), 868.

Guerrero, O. M., Chinchilla, M., \& Abrahams, E. (1997). Increasing of Toxoplasma gondii (Coccidia, Sarcocystidae) infections by Trypanosoma lewisi (Kinetoplastida, Trypanosomatidae) in white rats. Revista De Biologia Tropical, 877-882.

Guhl, F., Jaramillo, C., Vallejo, G. A., Cardenas, A., Arroyo, F., \& Aufderheide, A. (2000). Chagas disease and human migration. Memórias do Instituto Oswaldo Cruz, 95(4), 553-555.

Joshi, P. P., Shegokar, V. R., Powar, R. M., Herder, S., Katti, R., Salkar, H. R., ... \& Truc, P. (2005). Human trypanosomiasis caused by Trypanosoma evansi in India: the first case report. The American journal of tropical medicine and hygiene, 73(3), 491-495.

McGhee, B., \& Cosgrove, W. (1980). Biology and physiology of the lower Trypanosomatidae. Microbiological Reviews, 44, 140-173.

Morio, F., Reynes, J., Dollet, M., Pratlong, F., Dedet, J.-P., \& Ravel, C. (2008). Isolation of a protozoan parasite genetically related to the insect trypanosomatid Herpetomonas samuelpessoai from a human imunodeficiency virus-positive patient. Journal of Clinical Microbiology, 46(11), 3845-3847.

Nagle, R. B., Dong, S., Guillot, J. M., McDaniel, K. M., \& Lindsley, H. B. (1980). Pathology of experimental African trypanosomiasis in rabbits infected with Trypanosoma rhodesiense. 
The American Journal of Tropical Medicine and Hygiene, 29(6), 1187-1195.

Norman, F. F., \& Lopez-Velez R. (2013). Chagas disease and breast-feeding. Emerging Infection Diseases, 19(10), 1561-1566.

O'Connell, K. E., Mikkola, A. M.,Stepanek, A. M., Vernet, A., Hall, C. D., Sun, C. C., ... \& Brown, D. E. (2015). Practical murine hematopathology: a comparative review and implications for research. Comparative medicine, 65(2), 96-113.

Otero, S., Sulleiro, E., Molina, I., Espiau, M., Suy, A., Martin-Nalda, A., \& Figueras, C. (2012). Congenital transmission of Trypanosoma cruzi in non-endemic areas: evaluation of a screening program in a tertiary care hospital in BarceIona, Spain. The American Journal of Tropical Medicine and Hygiene, 87, 832-835.

Otto, M. A., da Silva, A. S., Gressler, L. T., Farret, M. H., Tavares, K. C. S., Zanette, R. A., ... \& Monteiro, S. G. (2010). Susceptibility of Trypanosoma evansi to human blood and plasma in infected mice. Veterinary Parasitology, 168(1-2), 1-4.

Pepin, J., \& Milord, F. (1994). The treatment of human African trypanosomiasis. Advances in parasitology, 33, 1-47.

Pereira, K. S., Schmidt, F. L., Guaraldo, A. M., Franco, R. M., Dias, V. L., \& Passoa, L. A. (2009). Chagas' disease as a foodborne illness. Journal of Food Protection, 72(2), 441-446.

Ponzi, M., Birago, C., \& Battaglia, P. A. (1984). Two identical symmetrical regions in the minicircle structure of Trypanosoma lewisi kinetoplast DNA. Molecular and biochemical parasitology, 13(1), 111-119.

Powar, R. M., Shegokar, V. R., Joshi, P. P., Dani, V. S., Tankhiwale, N. S., Truc, P., ... \& Bhargava, A. (2006). A rare case of human trypanosomiasis caused by Trypanosoma evansi. Indian Journal of Medical Microbiology, 24(1), 72.

Rayat, C. S., \& Vasishta, R. K. (2014). Wild rats as reservoir of Trypanosoma lewisi in Northwest India. Austin Journal of Pathology \& Laboratory Medicine, 1(2), 3.

Riedel, D. (1975). Reproduction, structure and host specificity of Trypanosoma (Herpetosoma) tamiasi sp. $n$. from the eastern chip- munk, Tamias striatus. The Journal of Protozoology, 22, 8-17.

Rocha, G., Martins, A., Gama, G., Brandao, F., \& Atouguia, J. (2004). Possible cases of sexual and congenital transmission of sleeping sickness. The Lancet, 363(9404), 247.

Rodriguez-Morales, O., Ballinas-Verduqo, M.A., Alejandre-Aquilar, R., Reyes, P. A., \& Arce-Fonseca, M. (2011). Trypanosoma cruzi connatal transmission in dogs with Chagas disease: experimental case report. Vector-Born and Zoonotic Diseases, 11(10), 1365-1370.

Rotureau, B., \& van den Abbeele, J. (2013). Through the dark continent: African trypanosome development in the tsetse fly. Frontiers in Cellular and Infection Microbiology, 3, 53.

Sato, H., Ishita, K., Matsuo, K., Inaba, T., Kamiya, H., \& Ito, M. (2003). Persistent infection of Mongolian jirds with a non-pathogenic trypanosome, Trypanosoma (Herpetosoma) grosi. Parasitology, 127, 357-363.

Schaub, G. A. (1994). Pathogenicity of trypanosomatids on insects. Parasitology Today, 10(12), 463-468.

Schwan, T. G., Lopez, J. E., Safronetz, D., Anderson, J. M., Fischer, R. J., Maïga, O., \& Sogoba, N. (2016). Fleas and trypanosomes of peridomestic small mammals in sub-Saharan Mali. Parasites \& vectors, 9(1), 541.

Sharma, R., Gluenz, E., Peacock, L., Gibson, W., Gull, K., \& Carrington, M. (2009). The heart of darkness: growth and form of Trypanosoma brucei in the tsetse fly. Trends in Parasitology, 25, 517-524.

Shaw, G. L., \& Dusanic, D. G. (1973). Trypanosoma lewisi: termination of pregnancy in the infected rat. Experimental Parasitology, 33, 46-55.

Shikanai-Yasuda, M. A., \& Carvalho, N. B. (2012). Oral transmission of Chagas disease. Clinical Infectious Diseases, 54(6), 845-852.

Semenko, O. V., Galat, M. V., Shcherbak, O. V., Galat, V. F., \& Shulga, I. V. (2017). Peculiarities of dog babesiosis distribution in Kyiv city. Vestnik Zoologii, 51(6), 493-498.

Semenko, O. V., Vishnevskiy, D. O., \& Galat, M. V. (2020). Rol prisnovodnyh moluskiv 
Chornobylskogo radiaciyno-ekologichnogo biosphernogo zapovidnyka y poshurenni parazytarnyh hvorob [The role of freshwater molluscs of Chernobyl radiation and ecological biosphere reservre on spreading of parasitic diseases]. Naykovi dopovidi NUBiP Ukrainy, 4(86).

Stevens, J. R., \& Gibson, W. C. (1999). The evolution of pathogenic trypanosomes. Caderons de Saude Publica, 15(4), 673-684.

Uzonna, J. E., Kaushik, R. S., Gordon, J.R., Tabel, H. (1998). Immunoregulation in experimental murine Trypanosoma congolense infection: anti-IL-10 antibodies reverse trypanosome-mediated suppression of lymphocyte proliferation in vitro and moderately prolong the lifespan of genetically susceptible BALB/c mice. Parasite Immunol,20(6):293-302.

Viens, P., Targett, G. A. T., Wilson, V. C. L., Edwards, C. A. (1972). The persistence of Trypanosoma (Herpetosoma) musculi in the kidneys of immune CBA mice. Transaction of the Royal Society of Tropical Medicine and Hygiene, 66, 669-670.

Vishnevskiy, D. (2004). Osoblyvosti zoocenoziv Zony vidchydzhennya CHAES v pislyaavariynyi period [Features of zoocenoses of the Chernobyl Exclusion Zone in the post-accident period]. Naykovyi visnyk Uzhgorodskogo yniversytety. Seria: Biologiya, 15, 20-23.

\section{О. В. Семенко, А. І. Липська, Д. О. Вишневський, О. О. Бурдо, О. Б. Бойко,} В. Ф. Галат, М. В. Галат (2020). ТРИПАНОСОМОЗИ МИШЕЙ ЧОРНОБИЛЬСЬКОї ЗОНИ РАДІОАКТИВНОГО ЗАБРУДНЕННЯ. Ukrainian Journal of Veterinary Sciences, 11(4): 13-21, https://doi.org/10.31548/ujvs2020.04.002

Анотація. Одним із найбільш очевидних і довготривалих наслідків аварії на Чорнобильській атомній електростанції стало створення зони відчуження та зони безумовного відчуження. Есектт сукцесії проявляється в тому, що значна частина водних і наземних екосистем станом на 1986 рік були штучними або напівштучними системами, які перебували під регуляторним контролем людини. Паразитоценози можуть бути інформативним фрактором процесів, що відбуваються в екосистемах. Будь які зміни в популяції хазяів призводять до змін у популяціях паразитичних організмів. Рівень співвідношення у паразито-хазяїнних системах залежить від сили і впливу зовнішніх факторів. 3 метою вивчення паразитарних систем зони відчуження як інфрормативних показників було відібрано гризунів. Серед досліджуваних мишей на наявність збудників паразитарних захворювань були польові (Apodemus agrarius) ma жовтогорлі (Apodemus flavicollis). Булопроведеноїхнєдослідження на наявністьзбудників кровопаразитарнихзахворювань.

Дослідження мазків крові мишей виявило наявність збудників паразитарних та інсрекційних захворювань крові у всіх досліджуваних тварин. Серед збудників цих хвороб були виявлені Trypanosoma spp., Babesia spp., Rickettsia spp. ma інші. Trypanosoma spp. було вперше виявлено на території України в мазках крові 3 мишей серед досліджуваних, які становили 25\% (95\% довірчі інтервали 6,8-54,1). Кількість паразитів у 200 полях зору мікроскопа досліджуваних мишей коливалася від 2 до 25. Трипаносомози тварин і людини $\epsilon$ надзвичайно поширеними. Збудники-трипаносоми спричиняють багато різних хвороб великої рогатої худоби, коней, верблюдів, дрібної рогатої худоби, зокрема, сурру, дурину, нагану та інші. Крім того є причиною гамбійської й родезійської сонної хвороби людини.

Ключові слова: кровопаразитарні хвороби, миші, Apodemus flavicollis, Apodemus agrarius, Trypanosoma spp 